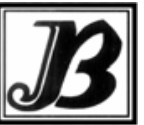

J. bio-sci. 18: 128-133, 2010

ISSN 1023-8654

http://www.banglajol.info/index.php/JBS/index

\title{
ANTIBACTERIAL ACTIVITY IN THE LEAVES OF SEVEN BITTER MEDICINAL PLANTS OF BANGLADESH
}

\author{
M T H Molla*, M S Ahsan, M T Alam, M E Haque* \\ Department of Applied Chemistry and Chemical Engineering, University of Rajshahi, Bangladesh.
}

\begin{abstract}
Context: Development of resistance in human pathogens against conventional antibiotic necessitates searching indigenous medicinal plants having antibacterial property. Seven medicinal plants used actively in folklore, ayurvedic and traditional system of medicine were selected for the evaluation of their antimicrobial activity for this study.

Objectives: Evaluation of the effectiveness of some medicinal plant extracts against four Gram-positive and five Gram-negative bacteria.

Materials and Methods: The antibacterial activity of the crude ethanolic extracts obtained from the leaves of seven medicinal plants; viz., Andrographis paniculata, Catharanthus roseus, Adhatoda vasica, Vitex vegundo, Aloe vera, Flacortia ramontchi and Nyctanthes arbortristis were tested against nine bacteria at concentrations of 300-, 400- and $500 \mu \mathrm{g} / \mathrm{ml}$. Standard antibiotic disc kanamycin $(30 \mu \mathrm{g} / \mathrm{ml})$ was used for comparison. The minimum inhibitory concentration (MIC) of ethanolic extracts of the leaves of these medicinal plants were determined by testing the extracts on four Gram-positive and five Gram-negative bacteria by serial tube dilution method.

Results: All the extracts have notable antimicrobial activities against the test organisms. The ethanolic extracts of the leaves showed the highest antimicrobial activities against Bacillus megaterium and Shigella dysenteriae for An. paniculata, Ad. vasica and Al. vera; Bacillus subtilis and Salmonella typhi for C. roseus and N. arbortristis; Staphylociccus aureus and Salmonella typhi for V. vegundo; and Bacillus subtilis and Shigella sonnei for $F$. ramontchi respectively. The extract of the plants had MIC values ranging from 32 to $128 \mathrm{mg} / \mathrm{ml}$. All plant extracts showed no MIC against Shigella shiga and against Sarcina lutea only C. roseus showed MIC $128 \mathrm{mg} / \mathrm{ml}$.
\end{abstract}

Conclusion: The results revealed that the ethanolic extracts of the plants under present investigation have notable antimicrobial activities.

Keywords: medicinal plants, antimicrobial screening, MIC, bacteria.

\section{Introduction}

Historically, plants have provided a source of inspiration for novel drug compounds, as plant derived medicines have made large contributions to human health and well being. In our country we are using crude plants as medicine since Vedic period. A major part of the total population in developing countries still uses traditional folk medicine obtained from plant resources (Srivastava et al. 1996).

In the present era, plant and herb resources are abundant, but these resources are dwindling fast due to the onward march of civilization (Vogel 1991). Although a significant number of studies have been used to obtain purified phytochemicals, very few screening programmes have been initiated on crude plant materials. It has also been widely observed and accepted that the medicinal value of plants lies in the bioactive phytocomponents present in the plants (Veeramuthu et al. 2006). The greater susceptibility of gram-positive bacteria to plant extracts has been previously reported in South American (Paz et al. 1995), African (Kudi et al. 1999, Vlietinck et al. 1995) and Australian (Palombo and Semple 2001) medicinal plant extracts. Susceptibility differences between gram-positive and gram-negative bacteria may be due to cell wall structural differences between these classes of bacteria. The gram-negative bacterial cell wall outer membrane appears to act as a barrier to many substances including antibiotics (Tortora et al. 2001).

* Department of Pharmacy, University of Rajshahi, Bangladesh *Corresponding author: tamzid_hossain@yahoo.com 
Andrographis paniculata (Burm.f.) Wall. ex Nees., also known commonly as 'King of Bitters' (fam, Acanthaceae) extract is traditionally used as a medicine to treat different diseases in India, China and Southeast Asia including Bangladesh. In Scandinavian countries, it is commonly used to prevent and treat common cold (Cacer et al. 1997). Catharanthus roseus (L.) G.Don, or Vinca rosea L. (fam. Apocynaceae) is a commonly found herb in Bangladesh and is traditionally used in diabetis. Its alkaloids have hypotensive, seductive and also anti-cancerous property. Ethanol extract of leaf possess wound-healing activity too (Shivananda 2006). Adhatoda vasica Nees (fam. Acanthaceae) is a primary herb of the ayurvedic system used in the treatment of coughs, bronchitis, asthma and symptoms of common cold (Karthikeyan et al. 2009). Vitex negundo Linn. (fam. Verbenaceae) is a large aromatic shrub distributed throughout the greater part of Indian subcontinent up to an altitude of $1500 \mathrm{~m}$ in the outer Himalayas. Almost all parts of the herb are useful as a drug but the leaves and roots are most important and sold as drugs (Kirtikar and Basu 1933). Aloe vera (L.) Burm. f. or Aloe indica Royle (fam. Liliaceae) is a succulent with its origin in African continent. Its thick leaves contain the water supply for the plant to survive long periods of drought. Flacourtia ramontchi L.'Herit (fam. Flacourtiaceae), commonly called Governor's Plum or Madaraskara Plum in English, is a native of tropical Africa and Asia and its leaf is used in inflammation, jaundice and as blood purifier (Kirtikar and Basu 1933). Nyctanthes arbortristis Linn. (fam. Oleaceae) commonly known as Night Jasmine is one of the well known medicinal plants. Different parts of $N$. arbortristis are known to possess various ailments by rural mainly tribal people along with its use in Ayurveda, Sidha and Unani systems of medicines. Juice of the leaves is used as digestives, antidote to reptile venoms, mild bitter tonic, laxative, diaphoretic and diuretic (Nadkarni 1982).

Inspite of having the reported usefulness of the extracts of these plants in folk-medicine, no such works on their antimicrobiological investigations have so far been reported in the literature. Our present investigation deals with the extraction and microbiological investigations of the extracts of the seven bitter medicinal plants of Bangladesh.

\section{Materials and Methods}

Plant samples and extraction: Leaves of seven medicinal plants viz, An. paniculata, C. roseus, Ad. vasica, V. vegundo, Al. vera, F. ramontchi and $N$. arbortristis under present investigation were collected dried and separately grinded with a grinding machine to get powered materials. The powdered leaves were separately extracted with ethanol and the extracts were concentrated under reduced pressure.

Source of test microorganisms: Four Gram-positive bacteria (Bacillus megaterium, Staphylococcus aureus, Bacillus subtilis, Sarcina lutea) and five Gram-negative bacteria (Shigella shiga, Salmonila typhi-A, Escherichia coli, Shigella sonnei, Shigella dysenteiae) were collected from the Department of Pharmacy and the Department of Biochemistry and Molecular Biology, University of Rajshahi for determination of antimicrobial activity.

Preparation of fresh culture, standard discs and test samples: Slants were prepared by dispersing about $5 \mathrm{ml}$ of nutrient agar media in each test tube. The test tubes were sterilized in an autoclave at $121^{\circ} \mathrm{C}$ under a pressure of $15 \mathrm{lb} / \mathrm{sq}$. inch. for $15 \mathrm{~min}$. The sterilized test tubes were held in inclined position for solidification. The test tubes were then incubated at $37.5^{\circ} \mathrm{C}$. The test organisms were transferred from the culture medium to the slants. These were then incubated at $37.5^{\circ} \mathrm{C}$ for $24 \mathrm{~h}$. These fresh cultures were used within $2-3$ days.

Antibacterial activity: Antibacterial activity of the ethanolic extracts were evaluated by the disc diffusion method (Bauer et. al. 1966). The extracts were compared using kanamycin (30 $\mu \mathrm{g} / \mathrm{disc})$ as standard disc. Filter paper along with residual solvent was used as negative control. Crude ethanolic extracts of the leaves of above medicinal plants were dissolved separately in methanol to produce solutions having concentrations of 300-, 400- and $500 \mu \mathrm{g} / \mu \mathrm{l}$. Fresh culture of the test organisms in the slants were transferred into the plates 
of different pretridishes. Sample discs and standard disc were placed on the solidified agar plates. These were kept at $4^{\circ} \mathrm{C}$ in a refrigerator for $24 \mathrm{~h}$ in order to diffuse the extracts and antibiotics in the culture medium. The plates were incubated at $37.5^{\circ} \mathrm{C}$ for $24 \mathrm{~h}$. The antimicrobial activities of the crude ethanolic extracts were estimated by measuring the diameter $(\mathrm{mm})$ of the zone of inhibition of the organism. In each case, this was compared to that of standard sample.

Determination of minimum inhibitory concentrations (MIC): The above mentioned bacteria were utilized for determining the MIC of the ethanolic extracts. Nutrient broth medium and culture media were prepared following the standard methods (Reiner 1982). Kanamycin (30 $\mu \mathrm{g} / \mathrm{disc})$ was used as standards disc. Crude ethanolic extracts of the leaves of the above medicinal plants were transferred in separate vials containing $2 \%$ DMSO solution $(2 \mathrm{ml})$. This was mixed well to achieve sample solutions having concentration 1024 $\mu \mathrm{g} / \mathrm{ml}$. Nine sterilized test tubes containing 1-, 2-, 4-, 8-, 16-, 32-, 64-, 128- and $256 \mu \mathrm{g} / \mathrm{ml}$ sample solutions were prepared by serial dilution. Three test tubes containing media $\left(\mathrm{C}_{\mathrm{M}}\right)$, media plus sample $\left(\mathrm{C}_{\mathrm{MS}}\right)$ and media plus inoculums $\left(\mathrm{C}_{\mathrm{MI}}\right)$ were also maintained. Diluted inoculums $(10 \mu \mathrm{l})$ was added to each of the nine test tubes and mixed well. One $\mathrm{ml}$ of the sample was added to $\mathrm{C}_{\mathrm{MS}}$ and mixed well. $10 \mu \mathrm{l}$ of inoculums was added to $\mathrm{C}_{\mathrm{MI}}$ to observe the growth of the organisms in the media. $\mathrm{C}_{\mathrm{M}}$ containing media was used the check the sterility of the solution. The test tubes were incubated at $37.5^{\circ} \mathrm{C}$ for $24 \mathrm{~h}$. The lowest concentration of the extracts which inhibited microbial growth was recorded as the MIC.

\section{Results}

The diameters of the zones of inhibition derived by ethanolic extract of the leaves of seven plants are presented in Tables 1 and 2. An. paniculata shows maximum activity against B. megaterium and Shigella dysenteriae. No activity of the extract on Sarcina lutea, Shigella shiga, Shigella sonnei was experienced. The zones of inhibition produced by C. roseus were Staphylociccus aureus, B. subtilis, Sarcina lutea, Salmonella typhi, E. coli and Shigella dysenteria and the maximum activity was against B. subtilis and Salmonella typhi. Activity of the extract against $B$. megaterium, Shigella shiga and Shigella sonnei was not found. Ad. vasica shows the maximum activity against $B$. megaterium and Shigella dysenteriae. The extract had no or little activity against Sarcina lutea, Shigella shiga and Salmonella typhi. V. vegundo showed the maximum activity on Staphylociccus aureus and Salmonella typhi. The extract had a little activity on Sarcina lutea, Shigella shiga and Shigella sonnei. $A$. vera had the maximum activity against $B$. megaterium and $E$. coli. The extract showed no activity on Sarcina lutea, Shigella shiga and Shigella sonnei. F. ramontchi showed maximum activity against $B$. subtilis and Shigella sonnei. The activity of the extract against Sarcina lutea, Shigella shiga and Salmonella typhi was not found. $N$. arbortristis was very active against $B$. subtilis and Salmonella typhi. The activity of the extract against $B$. megaterium, Sarcina lutea and Shigella shiga was not found.

The MIC values of ethanolic extracts of the leaves of the above medicinal plants are shown in Table 3 . It is evident from the table that all extracts have notable antimicrobial activities against the test organisms. The extract of the plants had MIC values ranging from 32 to $128 \mathrm{mg} / \mathrm{ml}$. All plant extracts showed no MIC against Shigella shiga and against Sarcina lutea only C. roseus showed MIC $128 \mathrm{mg} / \mathrm{ml}$

\section{Discussion}

Sule et al. (2010) evaluated non-polar (dichloromethane) and polar (MeOH and aqueous) extracts of $A n$. paniculata (whole plant) for in vitro antibacterial activity against 12 skin disease causing bacterial strains using the disc diffusion method at three concentrations; 1000, 500, and $250 \mu \mathrm{g} / \mathrm{disc}$ respectively and found significant antibacterial activities against both the Gram-positive and Gram-negative bacterial strains tested. Diterpenoids and flavonoids are the main chemical constituents of $A n$. paniculata which are believed to be responsible for the most biological activities of this plant (Tang and Eisenbrand 1992). C. roseus has a variety of medicinal properties, such as antibacterial (Carew and Patterson 1970, Raza et al. 2009), 
Table 1. Antimicrobial activities of ethanolic extracts of Andrographis paniculata, Catharanthus roseus, Adhatoda vasica and Vitex vegundo leaves and standard Kanamycin (30 $\mu \mathrm{g} / \mathrm{disc})$

\begin{tabular}{|c|c|c|c|c|c|c|c|c|c|c|c|c|c|c|c|c|}
\hline \multirow{4}{*}{ Bacteria } & \multicolumn{16}{|c|}{ Diameter of zone of inhibition (mm) } \\
\hline & \multicolumn{4}{|c|}{ Andrographis paniculata } & \multicolumn{4}{|c|}{ Catharanthus roseus } & \multicolumn{4}{|c|}{ Adhatoda vasica } & \multicolumn{4}{|c|}{ Vitex vegundo } \\
\hline & \multicolumn{3}{|c|}{ Extract $\mu \mathrm{g} / \mathrm{ml}$} & \multirow{2}{*}{$\begin{array}{l}\text { Kana- } \\
\text { mycin } \\
\mu \mathrm{g} / \mathrm{ml} \\
30\end{array}$} & \multicolumn{3}{|c|}{ Extract $\mu \mathrm{g} / \mathrm{ml}$} & \multirow{2}{*}{$\begin{array}{l}\begin{array}{l}\text { Kana- } \\
\text { mycin } \\
\mu \mathrm{g} / \mathrm{ml}\end{array} \\
30\end{array}$} & \multicolumn{3}{|c|}{ Extract $\mu \mathrm{g} / \mathrm{ml}$} & \multirow{2}{*}{$\begin{array}{l}\text { Kana- } \\
\text { mycin } \\
\mu \mathrm{g} / \mathrm{ml}\end{array}$} & \multicolumn{3}{|c|}{ Extract $\mu \mathrm{g} / \mathrm{ml}$} & \multirow{2}{*}{$\begin{array}{l}\begin{array}{l}\text { Kana- } \\
\text { mycin } \\
\mu g / m l\end{array} \\
30\end{array}$} \\
\hline & 300 & 400 & 500 & & 300 & 400 & 500 & & 300 & 400 & 500 & & 300 & 400 & 500 & \\
\hline \multicolumn{17}{|l|}{ Gram-positive } \\
\hline Bacillus megaterium & 11 & 12 & 13 & 18 & - & - & - & 23 & 13 & 14 & 16 & 24 & 13 & 15 & 16 & 20 \\
\hline Staphylococcus aureus & 10 & 11 & 12 & 23 & 15 & 17 & 19 & 30 & 11 & 12 & 14 & 31 & 15 & 17 & 18 & 31 \\
\hline Bacillus subtilis & 09 & 10 & 12 & 17 & 16 & 18 & 19 & 24 & 12 & 13 & 14 & 27 & 15 & 16 & 18 & 24 \\
\hline Sarcina lutea & - & - & - & 18 & 13 & 16 & 17 & 20 & - & - & - & 21 & - & - & - & 21 \\
\hline \multicolumn{17}{|l|}{ Gram-negative } \\
\hline Shigella shiga & - & - & - & 19 & - & - & - & 22 & - & - & - & 22 & - & - & - & 20 \\
\hline Salmonila typhi-A & 11 & 12 & 16 & 24 & 14 & 16 & 18 & 25 & - & - & - & 29 & 13 & 14 & 17 & 26 \\
\hline Escherichia coli & 10 & 12 & 14 & 23 & 13 & 15 & 19 & 23 & 12 & 15 & 17 & 23 & 12 & 14 & 18 & 23 \\
\hline Shigella sonnei & - & - & - & 16 & - & - & - & 21 & 13 & 14 & 16 & 26 & - & - & - & 20 \\
\hline Shigella dysenteiae & 12 & 14 & 18 & 20 & 11 & 13 & 16 & 23 & 15 & 16 & 18 & 21 & 11 & 13 & 14 & 19 \\
\hline
\end{tabular}

Table 2. Antimicrobial activities of ethanolic extracts of Aleo vera, Flacortia ramontchi and Nyctanthes arbortristis leaves and standard Kanamycin $(30 \mu \mathrm{g} / \mathrm{disc})$

\begin{tabular}{|c|c|c|c|c|c|c|c|c|c|c|c|c|}
\hline \multirow{4}{*}{ Bacteria } & \multicolumn{12}{|c|}{ Diameter of zone of inhibition (mm) } \\
\hline & \multicolumn{4}{|c|}{ Aleo vera } & \multicolumn{4}{|c|}{ Flacortia ramontchi } & \multicolumn{4}{|c|}{ Nyctanthes arbortristis } \\
\hline & \multicolumn{3}{|c|}{ Extract $\mu \mathrm{g} / \mathrm{ml}$} & \multirow{2}{*}{$\begin{array}{c}\text { Kanamycin } \\
\mu \mathrm{g} / \mathrm{ml}\end{array}$} & \multicolumn{3}{|c|}{ Extract $\mu \mathrm{g} / \mathrm{ml}$} & \multirow{2}{*}{$\begin{array}{c}\text { Kanamycin } \\
\mu \mathrm{g} / \mathrm{ml}\end{array}$} & \multicolumn{3}{|c|}{ Extract $\mu \mathrm{g} / \mathrm{ml}$} & \multirow[t]{2}{*}{$\begin{array}{c}\text { Kanamycin } \\
\mu \mathrm{g} / \mathrm{ml}\end{array}$} \\
\hline & 300 & 400 & 500 & & 300 & 400 & 500 & & 300 & 400 & 500 & \\
\hline \multicolumn{13}{|l|}{ Gram-positive } \\
\hline Bacillus megaterium & 12 & 12 & 15 & 19 & 12 & 13 & 13 & 24 & - & - & - & 20 \\
\hline Staphylococcus aureus & 09 & 12 & 13 & 27 & 13 & 14 & 15 & 28 & 21 & 23 & 25 & 27 \\
\hline Bacillus subtilis & 10 & 13 & 14 & 17 & 13 & 15 & 17 & 30 & 23 & 26 & 28 & 31 \\
\hline Sarcina lutea & - & - & - & 20 & - & - & - & 22 & - & - & - & 17 \\
\hline \multicolumn{13}{|l|}{ Gram-negative } \\
\hline Shigella shiga & - & - & - & 19 & - & - & - & 21 & - & - & - & 19 \\
\hline Salmonila typhi-A & 12 & 14 & 15 & 30 & - & - & - & 30 & 20 & 24 & 28 & 29 \\
\hline Escherichia coli & 13 & 14 & 16 & 23 & 14 & 15 & 18 & 19 & 17 & 18 & 24 & 25 \\
\hline Shigella sonnei & - & - & - & 17 & 14 & 16 & 19 & 23 & 16 & 20 & 26 & 29 \\
\hline Shigella dysenteiae & 14 & 16 & 19 & 19 & 12 & 14 & 15 & 20 & 17 & 19 & 21 & 22 \\
\hline
\end{tabular}

Table 3. Minimum inhibitory concentration $(\mu \mathrm{g} / \mathrm{ml})$ of the crude ethanolic extracts.

\begin{tabular}{|c|c|c|c|c|c|c|c|}
\hline Bacteria & $\begin{array}{c}\text { Andrographis } \\
\text { paniculata }\end{array}$ & $\begin{array}{c}\text { Catharanthus } \\
\text { roseus }\end{array}$ & $\begin{array}{c}\text { Adhatoda } \\
\text { vasica }\end{array}$ & $\begin{array}{c}\text { Vitex } \\
\text { vegundo }\end{array}$ & Aleo vera & $\begin{array}{c}\text { Flacortia } \\
\text { ramontchi }\end{array}$ & $\begin{array}{l}\text { Nyctanthes } \\
\text { arbortristis }\end{array}$ \\
\hline \multicolumn{8}{|l|}{ Gram-positive } \\
\hline Bacillus megaterium & 32 & - & 32 & 64 & 32 & 128 & - \\
\hline Staphylococcus aureus & 128 & 64 & 128 & 32 & 128 & 64 & 64 \\
\hline Bacillus subtilis & 128 & 32 & 128 & 64 & 128 & 32 & 32 \\
\hline Sarcina lutea & - & 128 & - & - & - & - & - \\
\hline \multicolumn{8}{|l|}{ Gram-negative } \\
\hline Shigella shiga & - & - & - & - & - & - & - \\
\hline Salmonila typhi-A & 64 & 32 & - & 32 & 64 & - & 32 \\
\hline Escherichia coli & 64 & 64 & 64 & 128 & 32 & 64 & 128 \\
\hline Shigella sonnei & - & - & 64 & 128 & - & 32 & 128 \\
\hline Shigella dysenteiae & 32 & 128 & 32 & 128 & 128 & 128 & 64 \\
\hline
\end{tabular}


antifungal (Jaleel et al. 2007) and antiviral (Farnsworth et al. 1968). The alkaloids from C. roseus are famous for their anticancer activity (El-Sayed and Cordell 1981). Studies revealed its wound healing action in the rats (Nayak and Pinto-Pereira 2006). One of the isolated endophytes produced potential antimicrobial activity against some selected human pathogenic bacteria and a yeast (Roy and Banerjee 2010).

The previous results of the phytochemical analysis of Ad. vasica show that phenols, tannins, alkaloids, anthraquinones, saponins, flavanoids, aminoacids and reducing sugars are present in the leaves. It has also been shown that tannins are biologically active, against $E$. coli Staphylococcus aureus, Salmonila paratyphi and Candida albicans (Nair and Chandra 2004). The Preliminary phytochemical screening of successive extracts indicated presence of lipids, flavonoids, saponins, alkaloids, tannins, carbohydrates, terpenoids, and steroids in F. ramontchi leaves (Hardik et al. 2010). Antimicrobial susceptibility test showed that both the gel and the leaf of Al. vera inhibited the growth of S. aureus (Agarry et al. 2005). Methanol extract of $F$. ramontchi leaves possess broad-spectrum antimicrobial activity at concentration $10000 \mu \mathrm{g} / \mathrm{ml}$ whereas hydromethanolic and chloroform extracts having more or less antimicrobial activity (Lalsare 2011). Leaves extracts of N. arbortristis was found to have antimicrobial activity (Khandelwal et al. 1999). The chloroform extract of this plant was found to have both antibacterial and antifungal activity whereas the petroleum ether and ethanol extracts possess only antibacterial activity (Manisha et al. 2009, Verma et al. 2011).

Different extracts of Vitex negundo leaves were investigated by Aswar et al. (2009) for its antimicrobial and antifungal activity on five bacterial species and three fungal species. Among all extracts water-ethanol (50:50) extract showed maximum anti microbial and water extract showed maximum antifungal activity against all tested species. Most of the bacterial pathogens like Salmonella paratyphi, Klebsiella pneumonia, Vibrio choera, Streptococcus mutans and E. coli were found to be susceptible in leaf extracts of the Vitex negundo (Rose and Cathrin 2011). The present results supports the above findings.

\section{Conclusion}

From the foregoing evidences, we can conclude that the ethanolic extracts of the plants under present investigation possess appreciable antibacterial activities. The MIC values of the extracts have remarkable significance about the therapeutic effects of the active principles associated with the leaves of the plants.

\section{References}

Agarry OO, Olaleye MT, Bello-Michael CO. 2005. Comparative antimicrobial activities of aloe vera gel and leaf. Afr J Biotechnol 4 (12), 1413-1414.

Aswar PB, Khadabadi SS, Kuchekar BS, Rajurkar RM, Saboo SS, Javarka RD. 2009. In-vitro evaluation of anti-bacterial and anti-fungal activity of Vitex nigundo (Verbenaceae) Ethnobotanical Leaflets 13, 962- 967.

Bauer AW, Kirby WMM, Sherris JC, Thuruck M. 1966. Antibiotic Susceptibility Testing by a Standardized Single Disc Method, Am J Clin Pathol 44, 493-496.

Cacer DD, Hancke JL, Burgos RLA, Wickman JK. 1997. Prevention of common cold with Andrographis paniculata dried extract. A pilot double blind trial. Phytomedicine 4, 101-104.

Carew DP, Patterson BD. 1970. The effect of antibiotics on the growth of Catharanthus roseus tissue cultures. Lloydia 33, $275-277$. PMid:5495518

El-Sayed A, Cordell GA. 1981. Catharanthus alkaloids. XXXIV. Catharanthamine, a new antitumor bisindole alkaloid from Catharanthus roseus. J Nat Prod 44, 289-293. http://dx.doi:10.1021/np50015a009 PMid:7264679

Farnsworth NR, Svoboda GH, Blomster RN. 1968. Antiviral activity of selected Catharanthus alkaloids. J Pharmacol Sci 57, 2174-2175. http://dx.doi:10.1002/jps.2600571235 PMid:4303510

Hardik PH, Sangita SH, Bhavin LN. 2010. Pharmacognostic Studies on Leaves of Flacourtia ramontchi L.'Herit. Phcog J 2(13), 530-535.

Jaleel CA, Manivannan P, Sankar B, Kishorekumar A, Gopi R, Sonasundaram R, Panneerselvam R. 2007. Induction of drought stress tolerance by ketoconazole in Catharanthus roseus is mediated by enhanced antioxidant potentials and secondary metabolite accumulation. Colloids and surfaces. B, Biointerfaces, 60(2), 201-206. http://dx.doi:10.1016/j.colsurfb.2007.06.010 PMid:17643970 
Karthikeyan A, Shanthi V, Nagasathaya A. 2009. Preliminary phytochemical and antibacterial screening of crude extract of the leaf of Adhatoda vasica. L. Int J Green Pharm 3, 78-80. http://dx.doi:10.4103/0973-8258.49381

Khandelwal KR, Kadam SS, Singhama. 1999. Antibacterial acivity of the leaves of Nyctanthes arbortristis Linn. Indian J Nat Prod 15, 1820.

Kirtikar KR, Basu BD. 1933. Indian Medicinal Plants. Vol. I, 2nd ed., New Delhi: Bishen Singh Mahendra Pal Singh. 1933; p. 220-222

Kudi AC, Uhoh JU, Eduvie LO, Gefu J. 1999. Screening of some Nigerian medicinal plants for antibacterial activity. J Ethnopharmacol 67, 225-228. http://dx.doi:10.1016/S0378-8741(98)00214-1

Lalsare S, Verma PK, Khatak M, Ranjan S, Rajurakar S, Gurav SS. 2011. Anti-inflammatory and antimicrobial activity of Flacourtia ramontchi leaves. Int J Drug Dev Res 3(2), 308-313

Manisha V, Neha S, Satish S. 2009. Antimicrobial activity of stem bark extracts of Nyctanthes arbortristis Linn. (Oleaceae). Int J Phcog Phytochem Res 1(1), 12-14.

Nadkarni AK. 1982. Indian Materia Medica, Vol.I, 3rd ed. (Popular Prakashan Pvt. Ltd.,), 857-858.

Nair R, Chandra SV. 2004. Antibacterial activity of some medicinal plants of Sourastra region. J Tiss Res 4, 117-120.

Nayak BS, Pinto-Pereira LM. 2006. Catharanthus roseus flower extract has wound-healing activity in Sprague Dawley rats. BMC Comp Alter Med 21, 41. http://dx.doi:10.1186/1472-6882-6-41 PMid:17184528 PMCid:1764761

Palombo EA, Semple SJ. 2001. Antibacterial activity of traditional Australian medicinal plants. J Ethnopharmacol 77, 151-157. http://dx.doi:10.1016/S0378-8741(01)00290-2

Paz EA, Cerdeiras MP, Fernandez J, Ferreira F, Moyna P, Soubes ., Vazquez A, Vero S, Zunino L. 1995. Screening of Uruguayan medicinal plants for antimicrobial activity. J Ethnopharmacol 45, 67-70. http://dx.doi:10.1016/0378-8741(94)01192-3

Raza ML, Nasir M, Abbas T, Naqvi BS. 2009. Antibacterial activity of different extracts from the Catharanthus roseus. CEMED 3(1), 8185. http://dx.doi:10.1556/cemed.3.2009.1.7

Reiner R. 1982. Detection of Antibiotic Activity, In Antibiotic an Introduction, Roche Scientific Service, Switzerland, 21-25.

Rose CM, Cathrine L. 2011. Preliminary phytochemical screening and antibacterial activity on Vitex negundo Int J Curr Pharm Res 3(2), 99-101

Roy S, Banerjee D, 2010. Isolation of antimicrobial compound by endophytic bacteria from Vinca rosea. Int J Cur Res 5, 47-51.

Shivananda N. 2006. Influence of ethanol extract of Vinca rosea on wound healing in diabetic rats. J Biol Sci 6(3), 40-44.

Srivastava J, Lambert J, Vietmeyer N. 1996. Medicinal Plants: An Expanding Role in Development. The World Bank, Washigton, D.C., 8

Sule A, Ahmed QU, Samah OA, Omar MN. 2010. Screening for Antibacterial Activity of Andrographis paniculata Used in Malaysian Folkloric Medicine: A Possible Alternative for the Treatment of Skin Infections. Ethnobotanical Leaflets 14, 445-456.

Tang W, Eisenbrand G. 1992. Chinese drugs of plant origin, chemistry, pharmacology and use in traditional and modern medicine. Springer-Verlag 97-103.

Tortora GJ, Funke BR, Case CL. 2001. Microbiology: An Introduction, $7^{\text {th }}$ edition Benjamin Cummings Publishing, San Francisco, USA.

Veeramuthu D, Muniappan A, Savarimuthu I. 2006. Antimicrobial activity of some ethnomedicinal plants used by Paliyar tribe from Tamil Nadu, India. BMC Comp Alt Med 6, 35. http://dx.doi:10.1186/1472-6882-6-35 PMid:17042964 PMCid:1621080

Verma NS, Dwivedi S, Panigrahi D, Gupta SK. 2011. Anti-bacterial activity of root bark of Nyctanthes arbor-tristis Linn. Int J Drug Discov Herb Res1(2), 61-62.

Vlietinck AJ, Van Hoof L, Totte J, Lasure A, Vanden BD, Rwangabo PC and Mvukiyumwani J 1995. Screening of a hundred Rwandese medicinal plants for antimicrobial and antiviral properties. J Ethnopharmacol 46: 31-47. http://dx.doi:10.1016/03788741(95)01226-4

Vogel HG 1991. Similarities between various systems of traditional medicine. Considerations for the future of ethnopharmacology. J Ethnopharmacol 35: 179-190. http://dx.doi:10.1016/0378-8741(91)90071-K 